\title{
On Organizations and Oligarchies
}

\author{
Michels in the Twenty-First Century
}

\author{
Pamela S. Tolbert \\ Cornell University \\ Shon R. Hiatt \\ Cornell University
}

\section{INTRODUCTION}

A central problem for those interested in studying and explaining the actions of organizations is how to conceptualize these social phenomena. In particular, because organizations are constituted by individuals, each of whom may seek to achieve his or her interests through the organization, questions of how decisions are made in organizations and whose preferences drive those decisions are critical to explaining organizational actions. Although early organizational scholars spent much time wrestling with these questions (e.g. Barnard 1938; Simon 1947; Parsons 1956; March and Simon 1958), more recent work in organizational studies has tended to elide them, adopting an implicit view of organizations as unitary actors, much like individuals, and in particular, like individuals who operate with a coherent utility function that they seek to maximize (e.g. Porter 1985; Baum et al. 2005; Casciaro and Piskorski 2005; Mezias and Boyle 2005; Jensen 2006). Thus, organizational behavior is seen as reflecting efforts to achieve a specific goal, which is, presumably, that of enhancing the organizations interests.

While this may be the dominant conceptualization underlying much contemporary research, other work sharply questions the validity and usefulness of this approach to organizational analysis (March and Simon 1958; Cohen, March, and Olsen 1972; Jackall 1988). Studies in this tradition suggest that it is more appropriate in most instances to conceive of organizations as battlefields, constituted by shifting factions with differing interests that vie for control of the organization; hence, organizational actions should be viewed as reflecting the preferences of a victorious coalition at a given point in time. We suspect that, although most people's experience in organizations may make them sympathetic to the coalitional view and skeptical of the unitary actor view, the continuing predilection for the latter stems at least in part from problems of deriving systematic predictions of organizational behavior from a more chaotic, coalitional kaleidoscope perspective.

A different model of organizations is represented in the work of Robert Michels (1876-1936), who, nearly a century ago, offered his now-famous, pithy summary of the fundamental nature of organizations ([1911] 1962: 365): 'Who says organization, says oligarchy.' Drawing on his own experiences with early twentieth-century German political party organizations, Michels presented the drift to oligarchy as an 'iron law', inevitably resulting in the division of even the most expressly democratic organizations into two parts: a small stable set of elites and all the other members. His analysis 
offered a catalog of the processes and forces that produced such a division, and he postulated that the directives of the elite, while nominally reflecting the set of interests shared by all members, in actuality are driven by their own personal interests in the organization. His provocative (and very pessimistic) arguments have served as the basis for many studies over the years, particularly of organizations specifically formed to represent the interests of groups seeking to promote change in political arenas. Much of this work has been focused on assessing the purported inevitability of the emergence of oligarchies and defining the conditions of the iron law-i.e. those that affect the realization (or suppression) of oligarchic tendencies.

In this chapter, we argue that Michels's core arguments about the nature of oligarchies in organizations, and research generated in response to his work, are not only relevant to understanding the dynamics of political organizations but can be extended as a useful framework for thinking about important aspects of contemporary economic corporations as well. In making this argument, we highlight the parallels between Berle and Means's analysis (1932) of modern, publicly held corporations and that of Michels. Both analyses address the general organizational problem of ensuring representation of members' interests. In political organizations, it is the rank-and-file members' interests that leaders are charged with representing; in publicly held organizations, leaders are primarily responsible for representing the interests of stockholders, as the nominal owners' of the firm. In this context, we consider evidence and research on problematic corporate behavior to show how Michels's work provides a useful framework for understanding these problems and for formulating ways of addressing them.

\section{Where Do Oligarchies Come From?}

Michels's interest in the problems of oligarchy stemmed directly from his own experiences in the left-wing German Social Democratic party, which he joined as a university student and served in various administrative roles for several years. Michels became progressively disenchanted with the party, and particularly with the leaders, whom he viewed as cynically building a highly undemocratic political machine while mobilizing members based on a platform of increasing social equality and democracy. This ultimately led him to dissolve his relationship with the party, but his prior affiliation took a toll on his career prospects as a faculty member in the conservative circles of early twentieth-century German academia. Despite the sponsorship of Max Weber, his friend and intellectual mentor, he was unable to obtain a position in Germany and was forced to take a position at the University of Turin in Italy (Gerth and Mills 1946: 19). Convinced of the impossibility of sustaining truly democratic organizations, he eventually became a supporter of Benito Mussolini, on the grounds that strong leaders were most effective (Collins and Makowsky 2005).

His analysis of oligarchy in organizations clearly reflects his own experience in political and academic organizations. Ironically, he argued, it is the very success of organizations that sets in motion the evolutionary forces towards oligarchy. As organizations grow, the ability of members to participate directly in decision-making becomes progressively more constrained for a variety of reasons. At the most fundamental level, problems of finding times and places for all members to assemble for discussion of issues and decision making increase exponentially as the number of participants increases. In addition, his description of decision making in large groups foreshadows the sorts of social-psychological dynamics later 
elaborated by Janis's (1971) discussion of groupthink: Tt is a fact of everyday experience that enormous public meetings commonly carry resolutions by acclamation or by general assent, whilst these same assemblies, if divided into small assemblies... would be much more guarded in their assent' (Michels 1962: 64).

Organizational growth eventually requires delegating responsibility for most decision making to a small subset of members. Michels notes that such delegation is often done with great reluctance and the freedom of the delegates to make decisions without general membership approval may be sharply curtailed. Such restrictions, however, typically negate the advantages of delegation. Coleman (1974: 38-9) describes this problem well in the following extended discussion:

When men join together to create a corporate actor, whether it is an industrial corporation, a trade union, a neighbourhood association, or a political party, they find themselves confronted with a dilemma: to gain the benefits of organization, they must give over the use of certain rights, resources or power to the corporate body.... But each person, in turning over these rights, thereby loses a large measure of control over them. For the corporate actor may well act in a direction that he opposes - There is one apparent remedy for this: to create a constitution such that the corporate resources can be committed only when all corporators favour the action. This gives each person a veto power over corporate action. The defect of this solution, of course, is that the corporate actor is emasculated: it can do nothing in the absence of unanimity of the members.

In consequence, efforts to assert effective membership control typically are abandoned, and the delegates are increasingly empowered to set-agendas with little input from members, to offer recommendations for action with only brief expositions of rationales, and to make decisions on behalf of all members.

Moreover, organizational growth almost always induces increased complexity - the creation of separate, specialized positions and offices to carry out different tasks-and this leads to a need for in-depth, hard-to-gain knowledge of the organization in order to carry out administrative functions (Blau, Heydebrand, and Stauffer 1966; Hall, Johnson, and Haas 1967; Pugh et al. 1968.) Increased complexity, in turn, gives rise to problems of coordination among task-interdependent subunits, which often lead to the development of formal rules and other more tacit integrative procedures (Lawrence and Lorsch 1967; Donaldson 1996; Sine, Mitsuhashi, and Kirsch 2006). Because mastery of these formal and informal rules, on which the day-to-day running of the organization rests, requires skills and experience that are not readily available among the rank-and-file members, the leaders of the organization gain additional power over the latter and increased freedom to direct the organization as they see fit. Control of such 'administrative secrets' makes it difficult for members to question, let alone effectively challenge, decisions made by the leaders. Since this knowledge accumulates with tenure, the longer the tenure of the leaders, the more costly and difficult it is to replace them. Formal responsibility for managing communications within the organization, as well as those involving the representation of the organization to the outside world, further enhances leaders' power vis-ä-vis other members. As a result of these combined sources of power, Michels notes (1962: 70), 'Thus the leaders, who were at first no more than the executive organs of the collective will, soon emancipate themselves from the mass and become independent of its control.'

As leaders acquire more specialized, insider knowledge of the organization, they are also likely to acquire vested interests in maintaining their positions within the organization. Michels underscored the importance of leaders' material 
interests in motivating their behavior (1962: 207): '[T]hey hold firmly to their positions for economic reasons, coming to regard the functions they exercise as theirs by inalienable right... loss of their positions would be a financial disaster'. Thus, rather than making administrative decisions aimed at maximizing the nominal goals of the organization (those identified with the interests of the rank-and-file members), the leaders are inclined to govern in a way that ensures a flow of benefits specifically to themselves. And as their economic fortunes become tied to the survival of the organization, they become progressively disinclined to take actions that could lead to state or general social sanctioning, and to the ultimate disbanding of the organization. Sociologists have often referred to this (rather euphemistically) as a problem of 'goal displacement' or 'goal transformation' (Selznick 1943; Zald and Ash 1966; Jenkins 1977; Osterman 2006). ${ }^{1}$

Recognizing common interests in maintaining their positions, leaders begin to exhibit social solidarity, protecting each other against any and all efforts by lower level members to dislodge or discipline them. Serious challenges to the power and perpetuation of leaders in office that are led by insurgent members, if not readily suppressed, are typically dealt with through a process of cooptation: the heads of the insurgency are brought into the inner leadership circle. The larger membership, deprived of its own independent leaders, is thus effectively hobbled in its resistance to the established leadership.

In line with this, Michels (1962: 127) postulated the development of a sharp psychological as well as social division between the leaders and members. There is a clear connection in this part of Michels's analysis to Marx's and Weber's notion of class-based social action (with organizational leaders as a klasse für sich). Organizations are portrayed as inevitably divided into an elite group and others, with the elites having material interests that are distinct from, and at least partially opposed to, those of the others. The activities of the larger membership are directed and exploited by the elite for the latter's benefit. Thus, Michels's analysis points to the use of a class-based model in explaining and analyzing organizational behavior (see Hinings and Tolbert 2008 for a discussion of such models within an institutional theoretic approach).

\section{Are Oligarchies inevitable? Evidence from Political Organizations}

Over the years, this model has served as a key point of departure for scholars interested in studying various forms of democratically oriented organizations, from trade unions to economic cooperatives to social movements. Much of this work has aimed at identifying the limits to the iron law-that is, the conditions that may mitigate the drift towards oligarchic control.

\section{Research on Unions}

One of the best-known works in this tradition (perhaps the best known) is the historical analysis of the International Typographical Union (ITU), conducted by Lipset, Trow, and Coleman (1956) in the decade following World War II. Based on the claim that the ITU represented a rare, but clear exception to Michels's postulate of the inevitability

\footnotetext{
${ }^{1}$ While the defining features of oligarchies, in Michels's sense, have been subject to some dispute, several authors have argued that the concentration of resources in the hands of a small subset of a group, and the use of the resources specifically for the subset's benefit, is a critical element (see Cassinelli 1953; Acemoglu and Robinson 2007).
} 
of oligarchy (as evidenced by the maintenance of two distinct opposing political factions within the union, relatively frequent turnover in the union s key offices, and active participation and interest by members in union politics), the authors sought to identify aspects of the organization that had contributed to its exceptionalism. Their answer locates the maintenance of the organization's democratic functioning in unique events in the union's historical development, which gave rise to a culture in which contention was legitimate; this culture was maintained by certain structural features of the organization and by occupationally based informal social relations.

Structural features of the organization that supported the culture of democratic conflict included members' right to use referenda to bring issues to a vote (preventing leaders from complete agenda-setting control), minimal differences in the salaries of union officials and members (reducing leaders' economic interests in continued office-holding), and direct election of union leaders (versus selection of leaders by a smaller subset of representatives, whose votes could be more easily corralled). In addition, the union was characterized by very dense interpersonal ties and patterns of interactions among the members, due in part to the odd working hours and conditions of printers' work that fostered social relations with other occupational members. Such relations prompted frequent informal discussions of union politics, thus contributing to members' ongoing interest and participation.

Although the analysis of the ITU offers intriguing insights into conditions that may help check tendencies towards oligarchic drift, it is impossible to disentangle the relative contributions of the different countervailing factors. It is worth noting, however, that work on producer cooperatives points to some of the same organizational factors as counter valences to oligarchic tendencies as union studies. We turn next to this literature.

\section{Research on Producer Cooperatives}

Based on research on a variety of collectivist organizations (those that are employee-owned and dedicated to the maintenance of members' democratic control), Rothschild-Whitt (1979) proposed an ideal type of such organizations, defined by core characteristics. The most elemental of these is the refusal to take the initial step that Michels identified as the foundation of oligarchy: delegation of authority. In enduring collectivist organizations, she argued, all key decisions are made collectively and require consensual agreement of all members (1979: 512). Many of the other characteristics in her model flow from this fundamental property, including: minimal formal rules, selection of members with similar, homogeneous values, and a minimum of specialization and division of labor.

While severely limiting the delegation of authority may be feasible only in a very small set of organizations, other characteristics linked to membership control in her proposed model are similar to those suggested by the ITU study. For example, she suggested that the minimization of reward differentials among the membership, and lack of opportunities for individual career advancement contributed to a focus on collective interests. This parallels Lipset et al's observations of the beneficial effects of limiting the differences in the compensation of the union leaders and the rank and file. An additional characteristic of collectivist organizations identified in her analysis, one that is relevant to Michels's arguments about 'administrative secrets' enhancing leaders' power, is the demystification of expertise through the rotation of jobs among members and through a culture that encouraged the sharing of special knowledge possessed by individual 
members. This relates to a key debate within the literature on social movement organizations (SMOs), concerning the impact of professional leadership on SMOs' change efforts.

\section{Research on Social Movement Organizations}

Clearly reflecting the influence of Michels's legacy, a handful of early studies of social movements focused specifically on the transformation of movements into bureaucratic organizations and the accompanying transformation of movement goals. One exemplar of this tradition is a study of The March of Dimes, a movement begun in the 1930s, which mobilized thousands of volunteers over a twenty-year period to obtain support for medical research on polio (Sills 1957). The study documented the way in which the discovery of a vaccine in the 1950s for the disease led to a crisis within the organization, which by that time had developed a full-time administrative staff, entered into long-term contracts for facilities, and gained considerable expertise in managing volunteer employees. Rather than disbanding with the achievement of its objective, the organization redefined its goals as raising funds to combat birth defects, a much broader and presumably less easily achieved goal (see also Messinger 1955; Zald and Denton 1963 for similar case studies of the transformation of social movements into organizations, and the accompanying transformation in mission).

Although rarely made explicit in these analyses, the suggestion that, at base, such transformations are probably driven largely by the leaders' own interests in perpetuating the organization lurks very close to the surface. But specific concern with the exploitation of the rank and file by the leaders as a part of such transformation, made clear in Michels's analysis, is much less evident. This is also true of more contemporary work in this tradition, which has centered on a debate over the relative advantages and costs of professional, more centralized leadership in social movement organizations.

This debate has its roots in the emergence of the theoretical tradition of resource mobilization in the 1970s, which drew attention to a largely neglected issue in the literature-the organizational properties of effective movements (Gamson 1975; McCarthy and Zald 1977; Tilly 1978). Within this context, researchers renewed attention to the question raised in earlier work of the conditions that fostered a more participatory form of movement organization (versus a more professionalized, oligarchic form) and opened a debate on the relative costs and benefits of these different forms.

In the first flush of the anti-corporate, anti-bureaucratic ideology that blossomed in the 1960s and early 1970s, many new movements in the United States sought to maintain membership control through consciously minimizing formal organization and hierarchical delegation of authority in particular. Some soon rediscovered the validity of Michels's suggestion that high levels of participatory control can pose severe constraints on collective action (Freeman 1972) and came to view often ineffective participatory arrangements as part of a cultural identity that they shunned (Polleta 2002; Clemens and Minkoff 2004). ${ }^{2}$ Perhaps partly in response to this (and certainly in line with it), the professionalization of social movements - the development of a group of essentially freelance administrators with experience both in organizing protest activities and fund-raising for political causes-emerged as a distinctive trend by the mid-1970s (McCarthy and

\footnotetext{
${ }^{2}$ Despite this perception, Clemens's (1993) research provides persuasive evidence that participatory forms are not necessarily ineffective, but may require that participants have sufficient personal and social resources needed for non-hierarchical coordination of actions.
} 
Zald 1977; Jenkins 1977; Gelb and Palley 1982), one that was easily identified with potential problems of oligarchy.

In this context, researchers soon became embroiled in a debate over the relative merits and costs of more professionalized control of social movements, with some research suggesting that this resulted in the cooptation and deradicalization of movements' in terms of both tactics and goals (e.g. Piven and Cloward 1977; McAdam 1983), and others arguing that such conservative effects were far from inevitable (Jenkins 1977; Ruecht 1999), and that even when professionalization did lead to greater conservatism, it also helped to prevent the movement's complete dissolution (Staggenborg 1988). Unfortunately, this debate has been cast largely in oppositional terms -that is, the guiding question has been whether the professionalization of movement leadership generally has a positive or negative effect on the maintenance and achievement of the initial movement goals. Consequently, it provides few insights into the conditions that may mitigate or exacerbate professionalization's impact on these outcomes or on leadership entrenchment. One exception to this is provided by a study by Osterman (2006, which examined the mechanisms that allowed a social changeoriented non-government organization (NGO) with a highly bureaucratized, oligarchically structured leadership to maintain high levels of involvement by the volunteer workers in the organization. His analysis suggests that this was the result of training provided to volunteers that encouraged and facilitated their participation, and thus gave rise to a culture in which discussion of (and dissension from) established policies was valued and accepted.

As noted, though, the literature on social movement organizations has shown a surprising lack of concern with a key issue raised by Michels, leaders' propensity to exploit the organization specifically for their own gain. This issue has been engaged, however, in a very different context, an analysis of changes in economic organizations that was first laid out in the early 1930s.

\section{Extending Michels TO ECONOMIC ORganizations}

As suggested at the outset of this chapter, a Michelsian view of the nature of organizations is in many respects quite consistent with the analysis of Adolf Berle and Gardiner Means, a lawyer and an economist, respectively, whose classic work, The Modern Corporation and Private Property (1932), addressed some of the implications of the replacement of owner-directed firms by managerially directed firms as dominant organizational forms in the American economy. ${ }^{3}$ We now turn to consider Berle and Means's basic thesis, along with analyses that have sought to address their arguments, offered primarily by economists under the banner of agency theory.

Writing in the early throes of the economy-shaking depression of the 1930s, Berle and Means focused on two major trends that distinguished the economic landscape of the period from earlier eras. The first was the increasing flow of capital into a smaller and smaller set of firms that were, necessarily, becoming clearly distinguished in both size and economic power from other firms. The second was the dispersal of ownership of these firms through the purchase of shares by larger and larger numbers of individuals; as a consequence, most stockholders held only a small fraction of a

\footnotetext{
${ }^{3}$ Roy (1997) provides a very provocative and compelling account of the historical processes that enabled large publicly held corporations to dominate the US economy by the time Berle and Means offered their analysis.
} 
company's total shares, and their exercise of stockholder power (e.g. through selling off their shares) generally had no discernible effect on the functioning of the organization.

As a result, they argued, top-level managers of these organizations were no longer constrained to follow the wishes of stockholders, the nominal owners of the firm, and were empowered to run it in ways that they saw fit-which were likely to entail enhancement of their own positions, either through continuing organizational growth (allowing them to derive both greater status and compensation from their positions) or through siphoning off resources from the firm via various corporate perks for managers (represented as part of normal, if perhaps not absolutely necessary, business operations) or both. In their words:

In its new aspect the corporation is a means whereby the wealth of innumerable individuals has been concentrated into huge aggregates and whereby control over this wealth has been surrendered to a unified direction. The power attendant upon such concentration has brought forth princes of industry, whose position in the community is yet to be defined... The direction of industry by persons other than those who have ventured their wealth has raised the question of the motive force back of such direction and the effective distribution of the returns from business enterprise. ([1932] 1991: 4)

Much of their discussion of the nature of stockholders' loss of control over the firm's direction focused on the way in which managers are elected by stockholders. This typically entails ratification of a slate of candidates chosen by the board of directors-who are themselves originally selected by top managers-through proxy votes. As they note, the slate (unsurprisingly) is usually composed of existing management members. In the absence of social connections and organization among stockholders, it is virtually impossible for any significant voting block to emerge to change the selection process, resulting in a 'self-perpetuating oligarchy' (Mizruchi 2004: 581). The similarity of this depiction to Michels's discussion of the machinations of leadership groups to preserve the illusion of democracy while perpetuating themselves in office is noteworthy.

In addition to their role in selecting the board of directors, Berle and Means also alluded to the ability of managers to control information about and communications within organizations as an element of their autonomy from stockholder control. They observe that management 'may issue financial statements of a misleading character or distribute informal news items which further its own market manipulations' ( [1932] 1991:115). Although not elaborated, this observation offers a parallel to Michels's arguments about control of information as a source of leadership power.

Also like Michels, Berle and Means suggest that the interests of the management (leaders) commonly diverge from those of the stockholder owners (rank and file). They catalog some of the ways in which such diverging interests may be manifested, a catalog that is particularly interesting in light of some of the organizational debacles of the early twentyfirst century:

Profits may be shifted from a parent corporation to a subsidiary in which the controlling group has a large interest. Particularly profitable business may be diverted to a second corporation largely owned by the controlling group.... When it comes to the questions of distributing such profits as are made, self-seeking control may strive to divert profit from one class of stock to another, if, as frequently occurs, it holds interests in the latter issue. In market operations, such control may use 'inside information' to buy low from present stockholders and sell high to future stockholders. ([1932] 
1991:115)

Although they made a prima facie case for the existence of diverging interests between managers and owners, and outlined the mechanisms that could allow this divergence to be enacted, Berle and Means offered little in the way of empirical support for such. Despite voluminous documentation for other main points of their argument, such as the concentration of resources in key organizations and the dispersion of stock ownership, the only evidence provided for a divergence in the interests of owners and control (managers) consisted of a list of railroads sent into receivership as a result of financial mismanagement during a fifteen-year period around the turn of the twentieth century (see [1932] 1991: 113 n. 2). Later, more systematic research on this issue, based on the comparison of the economic performance of management-controlled and owner-controlled firms, turned up mixed evidence. While several studies found that profits and productivity were positively related to the concentration of stockholding (Monsen, Chiu, and Cooley 1968; Holl 1977; Hill and Snell 1989), others failed to turn up such a relation (Kamerschen 1968; Demsetz and Lehn 1985).

The latter results are consistent with one line of work, known as agency theory, whose main tenets were initially proposed by economists in response to Berle and Means's arguments. Classic work in this tradition acknowledges the potential divergence in the interests of stockholding owners (principals) and managers (agents of the principals), and focuses on identifying mechanisms that ensure agents do in fact run the firm in ways that are in concert with the principals' interests (Jensen and Meckling 1976; Fama and Jensen 1983; see also Davis 2005). Such mechanisms include designing managerial incentives to align their behavior with the interests of principals (e.g. through the provision of stockownership to managers) and removing managers whose firms are underperforming, either through direct dismissal by the board of directors or as a result of takeovers by other firms and investors. As Mizruchi (2004: 586) notes, however, these mechanisms have some noticeable costs from the standpoint of stockholders (see also Davis and Thompson 1994), and there is a fair amount of evidence, from a variety of sources, that suggests that they may be less than effective, for some of the reasons suggested by Michels.

\section{Are Managers' interests Aligned With Stockholders' interests? Symptoms Of Oligarchic PROBLEMS IN MOdERN BUSINESSES}

The faltering performance of many US firms in the face of increasing global competition in the 1980s created a context in which agency theorists' recommendations for increasing managerial stockholding as a means of dealing with problems of the separation of ownership and control were well received. Firms' relatively poor economic showing was often attributed to managers' lack of incentives to maximize shareholder value. In response, many firms undertook significant revisions in their managerial compensation practices, and in particular, increased stockholding as a component of executive pay. In larger companies today, salary represents a little less than 10 percent of CEOs' total compensation on average; the bulk of compensation is derived from bonuses and the exercise of stock options (Simon 2007; see also Gerhart and Rynes 2003; Murphy 1999). ${ }^{4}$

\footnotetext{
${ }^{4}$ Stock options refer to the right to purchase a fixed amount of a company's stock at a given price (the strike price, or exercise price). Executives may profit from stock options by purchasing and then selling stocks when the current value exceeds the strike price (see
} 


\section{Effects of Stock Options and Ownership}

Despite efforts to align managers' and shareholders' interests through managerial stock ownership and stock options, one does not need to look far to find examples of apparently significant misalignment. One part of the explanation for this is that top managers differ from average shareholders in one very key respect: the possession of specific, private information about the firm's plans and functioning - or 'administrative secrets' in Michels's terms. While the use of such knowledge in making decisions about selling or buying company stock is technically illegal, as insider trading, this is often hard to regulate, although there are some notable recent cases of top management prosecution for such activities. One example is provided by the case of Joseph Nacchio, former CEO of Qwest Communications, who is scheduled to go on trial (at the time of this writing) for forty-two counts of insider trading. In 2001 Nacchio sold $\$ 100.8$ million in shares, knowing that the company's financial woes were mounting and while presiding over an accounting scandal that led to a restated loss of \$2.48 billion in revenue for 2000 and 2001 (Lattman and Searcey 2007). Likewise, in the infamous debacle of the Enron Corporation, CEO Kenneth Lay and other top managers began selling off their company stock months before the firm's downward performance spiral became public knowledge, while its value was still high. Lay was later prosecuted for insider trading, in addition to conspiracy and fraud (McLean and Elkind 2004; US Securities and Exchange Commission 2004).

Moreover, the decision-making power of top managers enables them to take actions that other stockholders cannot, in ways that can adversely affect the others. This issue is reflected in the current controversy swirling around the issue of backdating stock options. ${ }^{5}$ This practice, apparently widespread before the passage of the Sarbane-Oxley Act in 2002 (Lie 2005), has resulted in serious economic fallouts in a variety of firms. An example is provided by KB Homes, a homebuilding company whose CEO, Bruce Karatz, was ranked among the top five in Forbes' yearly CEO Compensation Ranking for several years. Karatz became the target of a criminal probe by the Securities and Exchange Commission (SEC) for allegedly backdating his options to increase his pay by $\$ 41$ million. In response to protests by KB's shareholders to this alleged abuse, Karatz resigned and agreed to forfeit approximately $\$ 13$ million in options (Corkery and Forelle 2007). (It is worth noting, however, that he also began collecting a \$175 million exit package. The widespread provision of exit packages to executives is discussed below.) Research in Motion, Ltd. (RIM), the maker of Blackberry hand-held devices, offers another example. The company announced in early 2007 that stock-options backdating going back to the 1990s would lead to a financial restatement showing earnings reduced by $\$ 250$ million. The co-CEOs of RIM both agreed to pay about $\$ 4.25$ million of the amount back to 'to assist RIM in defraying costs' while two board members on the compensation committee resigned without public comment (Vascellaro 2007). And in a third, especially spectacular case, the top managers of Comverse Technology reportedly created fictitious employee names to generate hundreds of thousands of backdated options and then stashed them in a secret slush fund entitled I. M. Fanton (after Phantom of the Opera) (Bray 2007).

Gerhart and Rynes 2003 for a useful discussion of stock options as an element of compensation).

${ }^{5}$ Backdating of stock options involves granting an employee stock option with a date that is prior to the time the option was actually granted-typically a date on which the price of the stock was relatively very low. This right to purchase stocks, with knowledge of their actual future profitability, is clearly something that average stockholders lack, although it is not necessarily illegal. Backdating may require earnings restatements which can cause a company's stock values to plunge. 
Evidence indicates that these are far from isolated cases. By May 2007, the Wall Street Journal reported that over 160 companies were under accounting investigation by the SEC involving financial restatements totaling billions of dollars (Hughes 2007), leaving thousands of shareholders with plummeting revenues and asset values. More than a dozen executives have been indicted for illegal backdating, although only a handful have been actually convicted.

Thus, whether compensation that emphasizes the allocation of stock ownership and stock options to managers effectively aligns their interests with those of other stockholders, as agency theorists have argued, seems open to question. While a number of studies have found an overall positive relation between rates of managerial stockholding and

firm performance (e.g. Morck, Shleifer, and Vishny 1988; McConnell and Servaes 1990; Mehran 1995), this research also suggests puzzling non-linear effects that are inconsistent with agency theorists' predictions. Other research has found changes in managerial ownership to have very little effect on firm performance (Himmelberg, Hubbard, and Palia 1999). The link between the size of managerial stock options and firm performance is even more equivocal (Kole 1997; Hall and Liebman 1998; Hall and Murphy 2000). Since there is reason to expect the effects of stock options to differ from actual stock ownership, the-relatively weak effects of options on firm performance are not altogether surprising (Sanders 2001).

\section{Effects of Market and Board Discipline}

Similarly, a second mechanism posited to mitigate the effects of the separation of ownership and control, the 'market for corporate control' (the removal of top managers of a poorly performing firm following its acquisition by another firm), has been greatly blunted by the widespread adoption of 'poison pills' and 'golden parachutes' among large companies. Poison pills are stock-issuing arrangements that substantially increase the costs of taking over a firm; these require acquiring firms to pay inflated dividends to the takeover target's current stockholders. Poison pills were initially put in place by some firms in response to the wave of corporate raiding in the early 1980s; by the 1990s, the majority of large companies had adopted this defensive strategy (Davis 1991; Davis and Greve 1997). Golden parachutes are less directly aimed at preventing takeovers, but they serve to protect managers from adverse economic consequences if they are terminated or quit because of unanticipated events (including takeovers) by providing lucrative severance pay and other benefits. Interestingly, one of the justifications for such arrangements parallels Michels's observation that top-level elites seek to perpetuate themselves in office because of the financial benefits they derive. It is argued that golden parachutes discourage top managers from blocking takeovers that are in the interests of other stockholders just to preserve their own jobs (West Publishing Company 1998).

However, it appears that these arrangements often entail significant costs to stockholders - and in today's corporate environment these costs may be higher than those associated with managerial resistance to takeovers. Big awards paid out to exiting executives, notwithstanding poor performance, have infuriated investors. Despite the fact that Pfizer's stock declined nearly 37 percent during his five- year tenure, CEO Henry McKinnell was still awarded an exit package of over $\$ 200$ million in 2006 (Thurm and Lublin 2006). That same year, Robert Nardelli received a \$210 million severance package upon being fired from his head post at Home Depot. Nardelli received an annual compensation of over \$127 million, yet Home Depot's stock price failed to increase at all during his seven-year tenure (Mui 2007). 
Such revelations have inspired grass-roots movements among shareholders to increase executive accountability. From August 2006 to May 2007, over sixty companies voted on shareholder proposals that would give investors a nonbinding vote at the board level on executive compensation packages, although these 'say-on-pay' proposals have so far won the majority of shareholder votes in only two companies. It is doubtful that many companies will voluntarily adopt such proposals (Whitehouse 2007). However, in April 2007, the House began debating a bill that would give shareholders a nonbinding vote on the pay packages of senior executives as well as a right to vote on any golden parachute compensation plans (Labaton 2007).

Both the grass-roots and legislative efforts to address problems of apparent divergence in the interests of management and other stockholders would be unnecessary if the third mechanism, oversight of management by the boards of directors, were more effective. Although directors are legally charged with representing shareholders' interests by monitoring executive decisions and actions, academic research, as well as reporting by the popular press, suggest that efforts by boards to exercise real discipline over management are normally quite limited.

Research highlights a number of factors that are especially likely to enhance the power of organizational executives and limit board control. ${ }^{6}$ CEO duality, the assignment of CEO and board chairman responsibilities to the same individual, is perhaps the most notorious of these factors. Duality enables the organizational leader to command greater authority over board members by reducing the monitoring effectiveness of outside board members (Harrison, Torres, and Kukalis 1988; Wade, O'Reilly, and Chandratat 1990; Finkelstein 1992) and by making it more difficult for inside board members to act independently of the CEO (Westphal and Zajac 1995). As Jensen (1993: 36) noted, 'The function of the chairman is to run board meetings and oversee the process of hiring, firing, evaluating and compensating the CEO. Clearly the CEO cannot perform this function apart from his or her personal interest. Without the direction of an independent leader, it is much more difficult for the board to perform its critical function.

Studies have linked duality to the questionable practice of re-pricing options that are 'underwater', where the strike price is greater than the stock's current value (Pollock, Fischer, and Wade 2002), to higher levels of executive compensation overall (Westphal and Zajac 1995), to greater incidences of fraudulent financial reporting (O'Connor et al 2006), and to a greater likelihood of white-collar crime (Schnatterly 2003). In a similar way, CEOs are also likely to have greater power vis- a-vis the board when they are organizational incumbents, i.e. have risen through the ranks of the company to their position. Incumbency enables CEOs to form strong coalitions with other company executives as well as social ties with board members. In line with Michels's notion of the unification of elites, research has shown that CEOs have a significantly lower probability of being dismissed under these conditions (Shen and Cannella 2002).

Some evidence suggests that boards whose members are demographically similar to the CEO are more likely to take actions that enhance the CEO's position. For example, a study by Westphal and Zajac (1997) indicated that the more board

\footnotetext{
${ }^{6}$ To say that there is a vast literature on boards of directors and the distribution of power within corporations is to understate the case significantly. We consider only a relatively small part of this literature, just to provide a sense of why board control may be problematic.
} 
members share key demographic characteristics with the CEO, the less likely they are to put contingent compensation practices in place for the CEO. Along similar lines, research by Hallock (1997) showed that demographic similarity between board members and the CEO was associated with significantly higher levels of CEO pay. These advantages may be a key reason that more powerful CEOs are more likely to replace board members with ones who are similar to themselves than less powerful CEOs (Westphal and Zajac 1995; Zajac and Westphal 1996; see also Duguid 2006).

Finally, a number of studies have found a positive impact of executive tenure on CEO power (Wade, O'Reilly, and Chandratat 1990; Ocasio 1994). Again, in line with Michels's arguments, it appears that as length in office increases, CEOs acquire expert power through an increased familiarity with the firm's resources (Zald 1969) and personal power by appointing boards with supporters (Finkelstein and Hambrick 1989). Research suggests that longer CEO tenure empowers top managers to secure larger compensation packages, participate less in contingent compensation practices (Westphal and Zajac 1994; Westphal and Zajac 1995), and avoid being dismissed (Ocasio 1994) and replaced by inside succession (Shen and Cannella 2002).

Thus, there is clearly reason to question the extent to which existing interestaligning mechanisms succeed in minimizing the divergence of managers' and stockholders' interests in contemporary business organizations, and preclude the occurrence of the kinds of problems of oligarchic control and leadership exploitation suggested by Michels's model of organizations. In the following section, we consider the implications of this model for further research on firms and for policy.

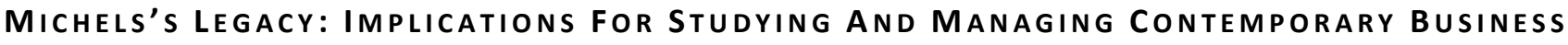 ORGANIZATIONS}

The preceding summary of the various problems that often have been identified with contemporary corporate management is intended to provide some graphic illustrations of the kinds of phenomena to which Michels's concepts and arguments might be applied. To make use of his analysis more systematically, however, there are a number of conceptual issues that will require further development. One primary issue for research involves the construction of both theoretical and operational definitions of oligarchy. A second issue entails thinking through the implications for policy and ongoing efforts at corporate reform. At this juncture, we can only identify some of the issues that seem most critical to us on each of these fronts and offer some initial thoughts on handling them.

\section{Research Implications}

At first blush, both theoretical and operational definitions of the phenomenon to which Michels draws attention would seem to involve a categorical state: either an organization is characterized by oligarchy or it is not. However, we suspect that, in the long run, it will be more useful to work on definitions and related measures that are continuous-that is, to treat oligarchy as a matter of degree. Although Michels does not define the concept specifically, his analysis suggests a number of different dimensions that are relevant.

One is, obviously, concentration of decision-making power in the hands of a relatively small subset of organizational 
members, or a high level of centralization, in the parlance of organizational theory. Thus, the degree of centralization would be one component of a definition of the degree of oligarchy. Unfortunately, while there is a long and venerable tradition of research on this aspect of structure (see Hall and Tolbert 2004; Scott and Davis 2007), this has not led to significant agreement on how best to measure it, and this issue merits more attention from organizational researchers.

A second dimension involves the entrenchment of a leadership group, or the stability of this group (i.e. longer average tenure would serve as a component indicator of a higher degree of oligarchy). Although much work on managerial entrenchment has focused simply on CEO tenure (e.g. Wade, O’Reilly, and Chandratat 1990; Westphal and Zajac 1995), we argue that using information on the top management team is preferable, since it is possible that turnover among CEOs as a result of scapegoating (Boeker 1992) may obscure the amount of stability that actually exists in the leadership group. In empirical studies, the degree of stability is apt to be partly a function of the parameters used to define this group.

In general, more objective criteria seem preferable to us, as well as ones that produce groups of a fairly consistent size. One pragmatic (albeit admittedly arbitrary) approach would be to use the top five managers, since standard archival resources often contain information on these (e.g. Hoover's Complete Guide to U.S. Public Companies), including length of tenure. An alternative-or additional- component of the operationalization of entrenchment might be the frequency of inside succession to the CEO position, based on the assumption that inside succession signals a more entrenched leadership group.

Yet a third dimension suggested by Michels is the degree to which leaders are insulated from control by the rank and file. In the context of contemporary economic organizations, this is most likely to involve relations between top managers and the board of directors, since by law, managers are charged with acting in the fiduciary interests of stockholders, and the board is charged with ensuring such. ${ }^{7}$ It is common to use the proportion of outsiders on the board (those not employed by an organization) as a reverse indicator of leadership insulation (Westphal and Zajac 1997: 512), based on the assumption that such directors will be more likely to question a CEO's decisions. Indeed, one of the key recommendations for corporate reform has been to require more outside directors (Fama and Jensen 1983), though the evidence on whether such directors actually ensure CEOs' and managers' commitment to stockholder interests is equivocal (see e.g. Wade, O'Reilly, and Chandratat 1990; Duguid 2006). Alternative indicators might include CEO duality, or the appointment of the current CEO as board chair, and/or the proportion of board members appointed by the current CEO.

Although individual dimensions (and even single measures) could serve as indicators of oligarchy in empirical studies, the development of a multidimensional measure is conceptually more defensible for examining the validity of Michels's arguments. Such examinations could focus on the relationship between the measure of oligarchy and an array of outcomes suggested in the preceding review of corporate problems, including firms' adoption of arrangements that often benefit managers but provide questionable value to shareholders (such as poison pills and golden parachutes), the frequency of

\footnotetext{
${ }^{7}$ Note that Berle and Means considered the board to be part of the management structure: 'direction of the activities of the corporation is exercised through the board of directors' (quoted in Mizruchi 2004: 591). Although we appreciate the logic of this argument, we think it is more useful to conceptualize the board as representatives of stockholders-that is its legal function.
} 
backdating of stock options by managerial members, increasing executive compensation in the face of declining firm performance, and so forth. In this context, an interesting potential agenda for future research that, as far as we know, has not been examined at all is linking more objective indicators of oligarchy in a firm to managers' attitudes towards a stewardship role in the firm, and indicators of firms' orientation towards social corporate responsibility.

\section{Policy Implications}

A Michelsian view of organizations not only provides a framework for addressing a variety of research problems, extant research that has been generated by Michels's arguments also contains potentially useful insights for policy involving corporate reform. Looking across the studies from unions, economic cooperatives, and social movement organizations described above, we can identify a number of forces or arrangements that may minimize oligarchic abuses in business organizations.

One important factor, suggested by the ITU study, is the division of organizational elites-and here, we are thinking primarily of the board of directors - into self-consciously differing factions. Some small groups research suggests that formally assigning different expert roles to individuals can serve as an antidote to groupthink (Stasser and Titus 1985); by the same token, selecting or assigning directors to represent different factions of stockholders-employee stockholders, institutional investors, etc. - might provide impetus for fuller discussion of issues and enhance decision making within the organization. ${ }^{8}$

A second factor, pointed up in work on unions, collectives, and social movement organizations, is sharing knowledge of administrative expertise, thus diluting power based on the possession of 'administrative secrets'. Again, focusing on the board as the embodiment of stockholders' and non-managers' interests, one way to achieve this might be ensuring regular rotation of board chairmanships (and would entail eliminating CEO duality), and also setting term limits for board members. We recognize the trade-off here: shorter tenures for chairs and board members could also work against the acquisition of relevant knowledge of firm operations, thus weakening the effective power of the board by making it more difficult for members to challenge the rationales offered by managers for given action (see Lipset 1950). Hence, careful thought would have to be given to the details of such arrangements (e.g. the best length of term limits for effective participation by board members).

A third factor, also underscored in studies of unions and collectives, involves creating better mechanisms for input by stockholders (the corporate analog of the rank and file). Lipset, Trow, and Coleman (1956) provide persuasive documentation of the role of member-generated referenda as a means of countering union leaders' ability to control which issues were placed on the public decision-making agenda. The development of such mechanisms in economic corporations have, for many years, been thwarted by SEC rules, including ones that limited any communications among stockholders aimed at influencing stockholder votes (Black 1990). If more than ten stockholders were to be contacted,

\footnotetext{
${ }^{8}$ The same idea is embodied in the use of employee and labor director positions on the boards of German corporations, and in the representation of a wide range of stakeholders (including company employees, ex-government officials, trading partners, and bank officials) on the boards of Japanese corporations (Ahmadjian 2001).
} 
this was defined as an interest group, and if the group owned more than 5 percent of company stock, then the SEC required examination and approval of the communications in advance. Presumably such rules reflected a populist ideology, that is, the protection of the interests of smaller and unorganized investors, but in practice, these often enhanced managerial autonomy, as suggested by the fact that members of the Business Roundtable fought changes in these rules, changes that were finally implemented in 1992 and helped to set off a wave of institutional investor activism (Davis and Thompson 1994). While previous restrictions have been lifted, more systematic encouragement of input from investors could serve to ensure fuller consideration of different viewpoints in both board and day-to-day management decisions. Such arrangements have already been implemented in the United Kingdom, Australia, The Netherlands, and Sweden, where stockholders have been given advisory votes on annual decisions concerning executive compensation (Ossinger 2006; White and Patrick 2007).

Finally, as noted, recent work on social movement organizations suggests that organizational conservatism and managerial self-enhancement are not inevitable outcomes of conditions that are associated with oligarchic control; this is also affected by the culture of organizational leaders. In particular, Osterman's (2006) study suggests that a culture in which challenges to managerial decisions are accepted and valued can be cultivated by relevant training of both managers and subordinates (see also Postmes, Spears, and Cihangir 2001). Unfortunately, it is not clear that the current business training that most managers (and board members) have received encourages this. In fact, several studies suggest that greater exposure to economic theory, which predominates in business education, encourages individuals to give greater attention and weight to self-interests in making decisions, even decisions involving collective goods (Frank, Gilovich, and Regan 1993,1996; Marwell and Ames 1981). How to change this influence in management education is clearly a thorny issue (a bit like trying to move a graveyard, to borrow Woodrow Wilson's famous phrase), but one that, certainly from a Michelsian vantage point on organizations, warrants much more consideration by management scholars and educators. 


\section{REFERENCES}

ACEmoglu, D., and Robinson, J. A. (2007). 'On the Economic Origins of Democracy'. Daedalus, 136/1:160-1.

AHMADJIAN, C. (2001). 'Changing Japanese Corporate Governance'. Working paper, Center on Japanese Economy and Business, Columbia University.

ANDREAS, J. (2007). 'The Structure of Charismatic Mobilization: A Case Study of Rebellion during the Chinese Cultural Revolution'. American Sociological Review, 72: 434-58.

BARNARD, C. I. (1938). Functions of the Executive. Cambridge, Mass.: Harvard University Press.

Baum, J., Rowley, T. J., ShIPILOV, A. V., and CHUANG, Y.-T. (2005). 'Dancing with Strangers: Aspiration Performance and the Search for Underwriting Syndicate Partners'. Administrative Science Quarterly, 50/4: 536-75.

Berle, A. A., and Means, G. C. ([1932] 1991). The Modern Corporation and Private Property. New Brunswick, NJ: Transaction, New York: Harcourt, Brace and World.

BLACK, B. S. (1990). 'Shareholder Passivity Reexamined'. Michigan Law Review, 89/3: 520- 608.

Blau, P. M., Heydebrand, W, and Stauffer, R. E. (1966). 'The Structure of Small Bureaucracies'. American Sociological Review, 31/2:179-91.

BOEKER, W. (1992). 'Power and Managerial Dismissal: Scapegoating at the Top'. Administrative Science Quarterly, 37/4: 400-421.

BRAY, C. (2007). 'Former Comverse Officials Receive Prison Term in Options Case'. Wall Street Journal, May 11: A6.

CASCIARO, T, and PISKORSKI, M. J. (2005). 'Power Imbalance, Mutual Dependence and Constraint Absorption: A Closer Look at Resource Dependence Theory'. Administrative Science Quarterly, 50/2:167-99.

CASSINELLI, C. W. (1953). 'The Law of Oligarchy'. American Political Science Review, 47/3: 773-84-

Clemens, E. S. (1993). 'Organizational Repertoires and Institutional Change: Women's Groups and the Transformation of U.S. Politics, 1890-1920'. American Journal of Sociology, 98/4: 755-98.

and MinKoff, D. C. (2004). 'Beyond the Iron Law: Rethinking the Place of Organizations in Social Movement Research', in D. A. Snow, S. A. Soule, and H. Kriesi (eds.), The Blackwell Companion to Social Movements. Maldwell, Mass.: Blackwell Publishing.

COHEN, M. D., MARCH, J. G., and OLSEN, J. P. (1972). 'Garbage Can Model of Organizational Choice'. Administrative Science Quarterly, 17/1:1-25.

Coleman, J. S. (1974). Power and the Structure of Society. New York: W. W. Norton.

ColuINS, R., and MAKowsky, M. (2005). The Discovery of Society. Boston: McGraw Hill.

CORKERY, C., and Forelle, M. (2007). 'Former KB Officials Face U.S. Backdating Probe'. Wall Street Journal, February 24: A4.

DAVIS, G. F. (1991). 'Agents without Principles: The Spread of the Poison Pill through the Intercorporate Network'. Administrative Science Quarterly, 36/4: 583-613.

--(2005). 'New Directions in Corporate Governance'. Annual Review of Sociology, 31/1:

143-62.

-and Greve, H. R. (1997). 'Corporate Elite Networks and Governance Changes in the 1980s'. American Journal of Sociology, 103/1:1-37. 
and Thompson, T. A. (1994). 'A Social Movement Perspective on Corporate Control'.

Administrative Science Quarterly, 39/2:141-73.

DemSETZ, H., and LehN, K. (1985). 'The Structure of Corporate Ownership: Causes and Consequences'. Journal of Political Economy, 9316:1155-77.

Donaldson, L. (1996). 'The Normal Science of Structural Contingency Theory', in S. Clegg, C. Hardy, and W. Nord (eds.), Handbook of Organization Studies. London: Sage.

Duguid, M. M. (2006). 'Board Diversity and Corporate Financial Performance'. Master's thesis, Cornell University.

EtzıonI, A. (1958). 'The Functional Differentiation of Elites in the Kibbutz'. American Journal of Sociology, 64/3: 476-87.

FAmA, E. R, and JenSEN, M. C. (1983). 'Separation of Ownership and Control'. Journal of Law and Economics, 26/2: 301-25.

FinkElSTEIN, S. (1992). 'Power in Top Management Teams: Dimensions, Measurement and Validation'. Academy of Management Journal, 35/8: 505-38.

and HAMBrick, D. C. (1989). 'Chief Executive Compensation: A Study of the Intersection of Markets and Political Processes'. Strategic Management Journal, 10/3:121-34.

Frank, R. H., GILOVICH, T., and Regan, D. T. (1993). 'Does Studying Economics Inhibit Cooperation?' Journal of Economic Perspectives, 7/2:159-71.

(1996). 'Do Economists Make Bad Citizens?' Journal of Economic Perspectives, 10/1:187-92.

FreEMAN, J. (1972). 'The Tyranny of Structurelessness'. Ms. 2/1: 76-8, 86-9.

GAMson, W. A. (1975). The Strategy of Social Protest. Homewood, 111.: Dorsey Press.

GelB, J., and Palley, M. L. (1982). Women and Public Policy. Princeton: Princeton University Press.

Gerhart, B., and Rynes, S. L. (2003). Compensation: Theory, Evidence and Strategic Implications. Thousand Oaks, Calif.: Sage.

Gerth, H., and Mills, C. W. (1946). From Max Weber: Essays in Sociology. New York: Oxford University Press.

HALL, B. J., and LIEBMAN, J. B. (1998). 'Are CEOs Really Paid Like Bureaucrats?' Quarterly Journal of Economics, 113/3: 65392.

and MURPHY, K. J. (2000). 'Optimal Exercise Prices for Executive Stock Options'.

American Economic Review, 90/2: 209-14.

HALL, R. H., and TolberT, P. S. (2004). Organizations: Structures, Processes and Outcomes. Upper Saddle River, NJ: Prentice Hall.

JOHNSON, N. ]., and HAAS, J. E. (1967). 'Organizational Size, Complexity and Formalization'. American Sociological Review, 32/6: 903-12.

HALLOCK, K. F. (1997). 'Reciprocally Interlocking Boards of Directors and Executive Compensation'. Journal of Financial and Quantitative Analysis, 32/3: 331-44.

HARRISON, J. R., TORRES, D. L., and KUKALIS, S. (1988). 'The Changing of the Guard: Turnover and Structure Change in TopManagement Positions'. Administrative Science Quarterly, 33/2: 211-32.

HILL, C. W. L., and SNELL, S. A. (1989). 'Effects of Ownership Structure and Control on Corporate Productivity'. Academy of Management Journal, 32/1: 25-46.

Himmelberg, C. R, Hubbard, R. G., and Palia, D. (1999). 'Understanding the Determinants of Managerial Ownership and the 
Link between Ownership and Performance'. Journal of Financial Economics, 53/3: 353-84.

HiningS, C. R., and Tolbert, R S. (2008). 'Organizational Institutionalism and Sociology: A Reflection, in R. Greenwood, C. Oliver, K. Sahlin-Andersson, and R. Suddaby (eds.)> Handbook of Organizational Institutionalism. New York: Sage.

HoLL, R (1977). 'Control Type and the Market for Corporate Control in Large U.S. Corporations'. Journal of Industrial Economics, 25/4: 259-73.

Hoover's (2007). Hoover's Billion Dollar Directory: The Complete Guide to U.S. Public Companies. Austin, Tex.: Hoover's Business Press.

HUGHES, S. (2007). 'SEC Says It's “Looking at Subprime'”. Wall Street Journal, March 20.

JACKALL, R. (1988). Moral Mazes: The World of Corporate Managers. New York: Oxford University Press.

IANIS, I. L. (1971). 'Groupthink'. Psychology Today, 5/6: 43-4, 46, 73-4.

JENKINS, J. C. (1977). 'Radical Transformation of Organizational Goals'. Administrative Science Quarterly, 22/4: 568-85.

JENSEN, M. (2006). 'Should We Stay or Should We Go? Accountability, Status Anxiety and Client Defections'. Administrative Science Quarterly, 51/1: 97-128.

Jensen, M. C. (1993). 'The Modern Industrial Revolution, Exit and the Failure of Internal Control Systems'. Journal of Finance, 48/3: 831-80.

and MECKLING, W. H. (1976). 'Theory of the Firm: Managerial Behavior, Agency Costs

and Ownership Structure'. Journal of Financial Economics, 3/4: 306-60.

Kamerschen, D. R. (1968). 'The Influence of Ownership and Control on Profit Rates'. American Economic Review, 58/3: 43247.

KolE, S. R. (1997). 'The Complexity of Compensation Contracts'. Journal of Financial Economics, 43/1: 79-104.

LABATON, S. (2007). 'Democrats Seek Shareholder Voting on Executive Pay'. New York Times, April 19.

LATtMAn, D., and SearCey, P. (2007). 'Secret Signals: Ex-Telecom CEO Fields “Black Box" Trial Defense'. Wall Street Journal, March 16: Ai.

LAWRENCE, P. R., and LORSCH, J. W. (1967). Organization and Environment: Managing Differentiation and Integration. Boston: Graduate School of Business Administration, Harvard University.

LIE, E. (2005). 'On the Timing of CEO Stock Option Awards'. Management Science, 51/5: 805-12.

LIPSET, S. M. (1950). Agrarian Socialism. Berkeley: University of California Press.

Trow, M., and Coleman, J. (1956). Union Democracy. New York: Free Press.

MCAdAM, D. (1983). 'Tactical Innovation and the Pace of Insurgency'. American Sociological Review, 48/6: 735-54.

MCCARTHY, J. D., and ZALD, M. N. (1977). 'Resource Mobilization and Social Movements'. American Journal of Sociology, 82/6:1212-41.

McConnelL, J. J., and Servaes, H. (1990). 'Additional Evidence on Equity Ownership and Corporate Value'. Journal of Financial Economics, 27/2: 595-612.

McLeAn, B., and ElKIND, D. (2004). The Smartest Guys in the Room: The Amazing Rise and Scandalous Fall of Enron. New York: Portfolio Books.

MARCH, J. G., and SIMON, H. A. (1958). Organizations. New York: Wiley.

MARWELL, G., and AMES, R. (1981). 'Economists Free-Ride, Does Anyone Else? Experiments in the Provision of Public Goods, 
IV'. Journal of Public Economics, 15/3: 295-310.

Mehran, H. (1995). 'Executive Compensation Structure, Ownership, and Firm Performance'. Journal of Financial Economics, 38/2:163-84.

MessingeR, S. (1955). 'Organizational Transformation: A Case Study of a Declining Social Movement'. American Sociological Review, 20/1: 3-10.

MeZIAS, S. J., and BoYLE, E. (2005). 'Blind Trust: Market Control, Legal Environments and the Dynamics of Competitive Intensity in the Early American Film Industry, 1893-1920'. Administrative Science Quarterly, 50/1:1-34.

Michels, R. ([1911] 1962). Political Parties: A Sociological Study of the Oligarchical Tendencies of Modern Democracy. New York: Collier Books.

MIZRUCHI, M. S. (2004). 'Berle and Means Revisited: The Governance and Power of Large, U.S. Corporations'. Theory and Society, 33/3:579-617.

Monsen, R. J., CHIU, J. S., and Cooley, D. E. (1968). 'The Effect of Separation of Ownership and Control on the Performance of the Large Firm'. Quarterly Journal of Economics, 82/3: 435-51-

MORCK, R., SHLEIFER, A., and VISHNY, R. W. (1988). 'Management Ownership and Market Valuations: An Empirical Analysis'. Journal of Financial Economics, 20/1: 293-316.

Mui, Y. Q. (2007). 'Seeing Red over a Gold Parachute: Home Depot's CEO Resigns and his Hefty Payout Raises Ire'. Washington Post, January 4: D01.

MuRPhY, K. J. (1999). 'Executive Compensation', in O. Ashenfelter and D. Card (eds.), Handbook of Labor Economics. Amsterdam: North Holland.

OCASIO, W. (1994). 'Political Dynamics and the Circulation of Power: CEO Succession in U.S. Industrial Corporations, $1960-$ 1990'. Administrative Science Quarterly, 39/6: 285-312.

O'CONNOR, J. R, PrIEM, R. L., COOMBS, J. E., and GILLEY, K. M. (2006). 'Do CEO Stock Options Prevent or Promote Fraudulent Financial Reporting?' Academy of Management Journal, 49/6: 483-500.

OsSINGER, J. L. (2006). 'CEO Compensation Survey (A Special Report)’. Wall Street Journal, April 10: R6.

Osterman, P. (2006). 'Overcoming Oligarchy: Culture and Agency in Social Movement Organizations'. Administrative Science Quarterly, 51/4: 622-49.

PARSONS, T. (1956). 'Suggestions for a Sociological Approach to a Theory of Organizations, I'. Administrative Science Quarterly, 1/1: 63-85.

Piven, F. R, and Cloward, R. A. (1977). Poor People's Movements. New York: Vintage Books.

PolletA, F. (2002). Freedom Is an Endless Meeting: Democracy in American Social Movements. Chicago: University of Chicago.

Pollock, T. G., Fischer, H. M., and Wade, J. B. (2002). 'The Role of Power and Politics in the Repricing of Executive Options'. Academy of Management Journal, 45/12: 2273-83.

PORTER, M. E. (1985). Competitive Advantage: Creating and Sustaining Superior Performance. New York: Free Press.

Postmes, T, SPeARS, R., and CihAngIR, S. (2001). 'Quality of Group Decision Making and Group Norms'. Journal of Personality and Social Psychology, 80/6: 918-30.

Pugh, D. S., Hickson, D. J., Hinings, C. R., and TURner, C. (1968). 'Dimensions of Organizational Structure'. Administrative Science Quarterly, 13/1: 65-115. 
RotHSCHILD-WhITT, J. (1979). 'The Collectivist Organization: An Alternative to Rational- Bureaucratic Models'. American Sociological Review, 44/4: 509-27.

Roy, W. G. (1997). Socializing Capital: The Rise of the Large Industrial Corporation in America. Princeton: Princeton University Press.

RUECHT, D. (1999). 'Linking Organization and Mobilization: Michels' Iron Law of Oligarchy Reconsidered'. Mobilization, 4/2:151-69.

SANDERS, W. G. (2opi). 'Behavioral Responses of CEOs to Stock Ownership and Stock Option Pay'. Academy of Management Journal, 44/3: 477-92.

SChNATterly, K. (2003). 'Increasing Firm Value through Detection and Prevention of White-Collar Crime'. Strategic Management Journal, 24/7: 587-614.

ScOTT, W. R., and DAVIS, G. E (2007). Organizations and Organizing: Rational, Natural and Open System Perspectives. Upper Saddle River, NJ: Prentice Hall.

SELZNICK, P. (1943). 'An Approach to a Theory of Bureaucracy'. American Sociological Review, 8/1: 47-54.

Shen, W., and Cannella, A. A., Jr. (2002). 'Power Dynamics within Top Management and their Impacts on CEO Dismissal Followed by Inside Succession'. Academy of Management Journal, 45/12:1195-1206.

SILLS, D. (1957). The Volunteers: Means and Ends in a National Organization. Glencoe, 111.: Free Press.

SIMON, E. (2007). 'CEOs with \$1 Salary Still Make Millions'. Associated Press, June 11.

SIMON, H. A. (1947). Administrative Behavior. New York: Macmillan.

SINE, W. D., MitsuhaSHI, H., and KIRSCH, D. A. (2006). 'Revisiting Burns and Stalker: Formal Structure and New Venture Performance in Emerging Economic Sectors'. Academy of Management Review, 49/1:121-32.

StAgGenBoRg, S. (1988). 'The Consequences of Professionalization and Formalization in the Pro-choice Movement'. American Sociological Review, 53/4: 585-605.

StASSER, G., and TITUS, W. (1985). 'Pooling of Unshared Information in Group Decision Making: Bias Information Sampling during Discussion'. Journal of Personality and Social Psychology, 48/6:1467-78.

ThURM, J., and LUBLIN, S. S. (2006). 'Money Rules: Behind Soaring Executive Pay, Decades of Failed Restraints'. Wall Street Journal, October 12: Ai.

TILlY, C. (1978). From Mobilization to Revolution. Reading, Mass.: Addison-Wesley.

TURneR, J. H., and BeEghley, L. (1981). The Emergence of Sociological Theory. Homewood, 111.: Dorsey Press.

US Securities and Exchange Commission (2004). SEC Charges Kenneth L. Lay, Enron's Former Chairman and Chief Executive Officer, with Fraud and Insider Trading. Report \# 2004-94. Washington, DC.

VAsCellaro, J. E. (2007). 'RIM Sets Restatement, Shake-up on Board in Backdating Fallout'. Wall Street Journal, March 6: A3.

Wade, J. B., O'Reilly, C. A., and Chandratat, I. (1990). 'Golden Parachutes, CeOs and the Exercise of Social Influence'. Administrative Science Quarterly, 35/4: 587-603.

WeSTPHAL, J. D., and ZAJAC, E. J. (1994). 'Substance and Symbolism in CEOs' Long-Term Incentive Plans'. Administrative Science Quarterly, 39/3: 367-90.

(1995)- 'Who Shall Govern? CEO/Board Power, Demographic Similarity and New

Director Selection'. Administrative Science Quarterly, 40/1: 60-83. 
(1997). 'Defections from the Inner Circle: Social Exchange, Reciprocity and the

Diffusion of Board Independence in U.S. Corporations'. Administrative Science Quarterly, 42/1:161-83.

West Publishing Company (1998). West's Encyclopedia of American Law. Minneapolis: West Group.

White, E., and PAtrick, A. O. (2007). 'Shareholders Push for Vote on Executive Pay'. Wall Street Journal, February $26:$ B6.

Whitehouse, K. (2007). 'Pros: Give Holders a Say on Pay'. Wall Street Journal, April 4.

ZAJAC, E. J., and WeSTPHAL, J. D. (1996). 'Director Reputation, CEO-Board Power and the Dynamics of Board Interlocks'. Administrative Science Quarterly, 41/3: 507-29.

ZALD, M. N. (1969). 'The Power and Functions of Boards of Directors: A Theoretical Synthesis'. American Journal of Sociology, 75/1: 97-111.

----- and ASH, R. (1966). 'Social Movement Organizations: Growth, Decay and Change'.

Social Forces, 44/3: 327-44.

----- and Denton, P. (1963). 'From Evangelism to General Service: The Transformation of the YMCA'. Administrative Science Quarterly, 8/2: 214-34. 